\title{
Declaration of War - Between a Ceremony and a Strategy: The Case of Israel and Hamas in the Gaza Strip
}

\author{
Ilana Kwartin ${ }^{1} \&$ Kobi Michael ${ }^{2}$ \\ ${ }^{1}$ Law School, Sapir Academic College, Sderot, Israel \\ ${ }^{2}$ Department of Political Science, Ariel University, Ariel, Israel \\ Correspondence: Kobi Michael, Department of Political Science, Ariel University, Ariel, Israel and Jerusalem \\ Institute for Israel Studies (JIIS). E-mail: kobi@jiis.org.il
}

Authors' appearance order is alphabetic and their contribution is even.

Received: June 24, 2013 Accepted: July 4, 2013 Online Published: August 30, 2013

doi:10.5539/jpl.v6n3p198 URL: http://dx.doi.org/10.5539/jpl.v6n3p198

\begin{abstract}
Following the end of World War II, conflicts worldwide have changed greatly. "War," according to the classical definition, occurs with less and less frequency. Countries avoid involvement in formal warfare or categorizing conflicts with other entities as war.

The field of Conflict Resolution developed after World War II seeking the reasons for the outbreak of conflicts and clarifying new ways to settle them. More recently, a new approach called Conflict Transformation suggests converting the relationship between parties as the way to settle a conflict.

Israel is a party to many interlocking conflicts, one of which is the protracted and intractable conflict with Hamas in Gaza. This conflict is an extension of Israel's ethno-social conflict with the Palestinian people. The prominence of the conflict's violent dimension brings society to exhaustion and to develop a psychological infrastructure preserving and empowering the conflict's vitality.

In an era in which war was an acceptable means to solve disputes between countries, the 1907 Hague Convention obligated nations to declare war preceding the opening of hostilities. Israeli law governs declarations of war, but policy makers prefer to conduct large-scale military operations without a formal declaration. However, it is wider than a narrow legal act and is considered by Austin (1963) a "Speech Act," as well as a "ceremony" (Turner, 2004). Because a declaration of war contains a credible threat regarding the ability to "hurt" the other party, it serves as leverage to establish the necessary conditions between parties to reach a lasting peace. Although the idea of a declaration of war seems to conflict with the logic of Conflict Resolution, in actuality, applying the paradoxical principal of strategy - action against linear intuition-has the potential to settle the conflict through its transformative power.
\end{abstract}

Through those various paradigms of declaration of war, we conceptualize mollifiers and fomenters for the possibility to declare war in order to transform the conflict towards its resolution.

Keywords: ceremony, declaration of war, Hamas, Gaza, conflict transformation, mollifiers, fomenters, conflict resolution, strategy, paradoxical logic

\section{Introduction}

The directive to declare war is ratified in the Hague Convention (1907) as a prerequisite act of law prior to the onset of hostile activities between two parties. This refers to an era when war was an acceptable way of resolving disputes between nations. It is embedded in the Israeli law in Section 40(a) of the Basic Law: The Government, but is not implemented by political echelons, which embark on large-scale military activities with no formal declaration. A declaration of war also has constitutional implications because a war puts an end to legislation that applies in times of peace and replaces it with war laws and a new set of game rules.

However, as we understand it, a declaration of war is broader than a narrow legal act and is even recognized by Austin (1963) as speech act, or words that constitute the implementation of action, even if no "performative" action ensues. It is perceived as a rite of transition (Turner, 2004), representing a collective that is undergoing a change or some alteration of status or social conditions. Hence, in addition to its potential to lead to actual 
warfare, it can serve as a lever to establish conditions for the creation of agreements between the parties and the achievement of a lasting peace, insofar as it represents a real threat to the enemy's capacity to "inflict pain", even if that threat is not carried through (Gray, 2002). On the other hand, some claim that a declaration of war is irrelevant in present-day conflicts. In reality, formal declarations of war have become an extremely rare phenomenon since World War II (Elsea \& Grimmett, 2011).

The conflict between Israel and the Hamas movement in Gaza is an offshoot of the protracted ethno-national Israeli-Palestinian conflict. (Note 1) As in this case too, most conflicts in today's world are defined as low-intensity and are characterized primarily by asymmetry, difficulty in reaching resolution and victory, and involving both the civilian population and the international media. (Note 2)

In all such conflicts, including the one between Israel and Hamas, the predominant element is violence. This results in the erosion of the public and the development of a psychological infrastructure that creates a repertoire of behaviors for coping with the stress, while simultaneously justifying wartime actions taken by the leadership. Such an infrastructure maintains the conflict and even intensifies it (Bar-Tal, 2007). The level and scope of violence in such conflicts, in particular the one between Israel and Hamas, grows throughout the duration of the conflict. At the same time, as the violence grows, sensitivity to it decreases, eroded by its impact on the population in general and the international community in particular. Operation Cast Lead (2008-2009) which was an intense and carefully considered military operation that failed to produce decisive results is an example of such an escalation in violence.

This article merges four different research areas: Conflict Resolution, International Relations and Strategy, Anthropology and International Law. By analyzing the connections and interrelations between the fields, we develop a new theoretical and analytical infrastructure which helps create the paradoxical connection between a declaration of war and management or resolution of a low intensity conflict.

We maintain that conducting a military operation without a prior declaration of war in which a decisive resolution was not declared as an operational objective, constitutes no more than a temporary "band aid" and fails to address the real underlying issue of the dispute with a view to resolving or ending it altogether.

\section{The Contribution of the Article}

In this article we rely on an ideological and theoretical infrastructure borrowed from the world of conflict resolution $(\mathrm{CR})$ research. We would like to propose that a link exists between a directive to declare war and the possibility of resolving the conflict between Israel and Hamas in Gaza or at least transforming it to a less violent conflict. By means of an interdisciplinary analysis and the application of legal tools, together with the theoretical infrastructure of conflict resolution, we suggest that a declaration of war can transform a protracted conflict (Lederach, 2003), such as the one between Israel and Hamas in Gaza, and serve as a necessary preparatory stage for its decisive resolution or management.

It should first be stated that although a declaration of war as a tool appears to contradict the rationale behind conflict resolution, in fact the use of the paradoxical principle of strategy - i.e. engaging in action that contradicts linear intuition (Michael, 2011) - can successfully achieve the objective of settling a dispute using the proposed interpretation of employing a declaration of war as means for transformation. Within the limitations of a test case and in the absence of an actual declaration of war, the analysis is inevitably theoretical in nature, but in our view it has broader conceptual implications and presents a possible strategic opportunity.

\section{Declaration of War}

In the past, a declaration of war was considered an act of law that was a prerequisite to starting a war. The significance of the declaration was the abolition and end of any diplomatic and commercial relations between the two countries in question, and the annulment of any treaties between them. In today's world, the implications of a declaration of war (should it be issued) are less dramatic. In effect, since World War II formal declarations of war have become extremely rare (Elsea \& Grimmett, 2007).

There are widespread, acknowledged and established war laws within normative frameworks, which are widely recognized at both legal and practical levels by most countries of the world (Biton, 2006-2007). Such laws were formulated to arrange the obligations, rights, and privileges of parties to armed conflicts and apply both to the parties to the conflict and to relations between those parties and neutral parties. As such, the laws apply to both state and non-state organizations and are also binding on states and organizations that are not signatories to them.

As a general rule, international law imposes restrictions on the rights of nations to employ military force in their relations with other nations. Chapter I, Article 2(4), the Charter of the United Nations (1945) prohibits the use of force. It says members "shall refrain in their international relations from the threat or use of force against 
the territorial integrity or political independence of any state, or in any other manner inconsistent with the Purposes of the United Nations" (Seibel, 2003). The prohibition against the use of force as a rule of conduct is also binding on non-UN member nations. The only two exceptions to the prohibition on the use of force are a Security Council resolution permitting the use of force or warfare for individual or collective self-defense.

A belief prevails among researchers and jurists today that nations have waived their right to resolve conflicts by means of a declaration of war because of treaties to which they are party. (Note 3) Whether the entry into the arena of terror organizations and other non-state actors overturns that waiver and reinstates the right of nations to make formal declarations of war, as in the past, has yet to be addressed (Elsea \& Grimmett, 2007: 28). It is our belief that a declaration of war is also a ceremony, which as such has the innate and significant power to influence every group of people, whether defined as nation, organization, non-state entity, population or any other body. (Note 4)

\section{Declaration of War as a Ceremony - an Anthropological View}

When speaking of a declaration of war, Austin $(1963,2006)$ explains it as a "speech act", a declaratory performative sentence. Kenny (2010) argues that a declaration is a political act performed in public "as part of the regulation of power relations" (Kenny, 2010: 29). The very fact of making a declaration creates a new scenario even before any specific action occurs; thus the actual moment of declaration constitutes both a beginning and an end simultaneously, and has the power to bring about a transformation in the existing status.

Austin (1963) suggests acknowledging the power of words by paying special attention to the language and relevant contexts in which the words are spoken. For our purposes, Kenny (2010) explains that it is political activity, such as a declaration of war that shapes the legal dialogue addressing it, and not the other way around. Hence, even if a declaration of war is an anachronism and perhaps even unacceptable in strictly legal terms today, that does not detract from its optional impact at the political and transformative level. Since a formal declaration of war is determined in law and is deeply embedded in the world's tradition, it is perceived as a cross cultural act and applicable to different forms of government. As such it has retained its original ritual format. The ceremony of declaring war is recognized as representing a clear-cut division between two statuses - peace and war.

Thus a ceremony is a social phenomenon with symbolic meaning performed according to ritual rules which are clear, known, rigid, strict and common to all human society. It bears an important new message of change of status (Van Gennep, in: Turner, 2004: 87) and is in fact a rite of passage "accompanying any change of a collective nature from one state to another" (Turner, 2004: 147). It also emphasizes the lasting impact of the ceremony as a political tool for change or substitution (Ibid: 152).

Handelman (1990) underlines the importance of ceremonies as significant phenomena accompanied by symbols that are relevant to a particular group of people, whose performance may result in a major or minor transformation: "The result of ritual action is ... the small- or large-scale transformation of both the actor and the audience" (Trexler, in: Handelman, 1990: 11). Handelman, more than others, stresses ritual as a tool with the ability to produce change on a cosmological level, to generate a transformation in the world, in addition to change in the actors themselves. He explains that the format of the ceremony shapes the ritual experience and creates the meaning bestowed on it. Ceremonies have their own fixed order and predetermined accompanying documents. Their intention is to create a certain conscious and emotional situation, a social obligation and legitimization of the action and thus are undertaken in public, so as to broadcast the message and its meaning to the public and the world at large (Handelman, 1990).

\section{Conflict Resolution, Protracted Conflicts and Conflict Transformation}

The period after the end of World War II saw the dawning of the field of Conflict Resolution (CR), with 1957 marking its formal establishment. Conflict Resolution views conflicts as an inherent phenomenon to the human experience. Recognized theories in the field seek to discover the generic organizing principles of conflicts. (Note 5)

\subsection{The Conflict Transformation Approach}

Beyond the principal tenets of CR, a new approach, Conflict Transformation (CT), has arisen more recently. CT maintains that in cases of protracted and intractable conflicts, the objective should be to create a transformation of those conflicts (Botes, 2003). The theory of Conflict Transformation (Lederach, 2003) is perceived as an alternative to the traditional paradigms of Conflict Resolution, (Note 6) and for many researchers it represents a new development in the field (Ramsbotham, Woodhouse \& Miall, 2005(3), 22) and more comprehensive than other approaches (Botes, 2003). According to the theory of Conflict Transformation, in any given situation, psychological and other blocks prevent the resolution of a conflict. Hence it must be converted into a different 
kind of conflict, involving a transformation both of the conflict itself and of the socio-political system within which it exists (Botes, 2003). Since interpersonal relationships are at the heart of conflicts, intensifying them can actually result in their resolution via a change in some essential structure (Lederach, 2003). As we discuss in further sections of this article, declaration of war is a tool used to intensify the level of violence, creating structural transformation.

According to this approach, the desired transformation is one that creates "a turnaround in the dynamics of conflicting interactions" (Kriesberg, 2008: 407). The model of the approach is a spiral shape expressing circularity together with linearity, thus effectively emphasizing the complexity of the conflict process, whose progress is not exclusively linear. This approach aspires to help not only in the resolution or management of conflicts, but also by offering "[T] he ability to transform the dynamics of the conflict and the relationship between the parties - indeed to transform the very creators of the conflict" (Botes, 2003). As we later elaborate in this article, declaration of war changes the dynamics of the conflict and the relationships between the parties. It Shifts the rules of the game - from a sporadic front everywhere a population exists, to an organized and defined battle field.

Väyrynen identifies a series of transformations that are vital components of conflicts, in the absence of which the conflict may be diverted towards protracted violence and war (Väyrynen, in: Botes, 2003; Väyrynen, in: Ramsbotham, Woodhouse \& Miall, 2005(3), 205).

Among the transformations he proposes are:

Context Transformation: Since conflicts are rooted in social, regional and international contexts that contribute to their persistence, a change is first needed in the context itself before any change is possible in the relationships between the parties.

Structural Transformation: The structure of conflicts consists of the actors, the contradictory objectives of the parties and the relationships between the latter. If the conflict is based on the structure of the relationships between the parties, then a structural transformation (in the socio-political sense, as well as the structure and strength of the parties involved) will contribute to resolving the conflict. In asymmetrical conflicts, for instance, a structural transformation means bringing about a change in the relations between the state and the non-state actors.

\subsection{Protracted Conflict}

Azar (1985) points out that present-day conflicts are essentially generated by social causes and are characterized by extensive violence and open hostility. He coined the term "Protracted Social Conflict" (PSC) in reference to the Israeli-Arab conflict in the Middle East. He describes protracted conflicts as comprising a mixture of ethnic and inter-State elements and "hostile interactions which extend over long periods of time with sporadic outbreaks of open warfare fluctuating in frequency and intensity". The entire society is involved in a protracted conflict, creating a national identity and solidarity. Despite periods of peace, no clear end to the conflict can be pinpointed, and a process leading to a conclusion can only be seen retrospectively (Azar, 1978).

Further, Rouhana and Bar-Tal (1998) denoted the term coined by Connor (1994): "Ethno-National Conflict", and defined the predominant characteristics of protracted intractable conflicts, i.e. continuous, total, central, violent and irresolvable. The weight and force of such characteristics varies from one conflict to another, but all of these qualities must exist in order to meet this definition. (Note 7)

\subsection{The Local Conflict as Protracted Conflict}

The local conflict is considered a protracted conflict since it fulfills all the above-mentioned features, including the presence of a psychological infrastructure. From a regional analysis (Levy, 2001), the conflict between the parties can be defined as an interlocking conflict (Kriesberg, 1980), inasmuch as it is interlocked with other conflicts and influenced by the reinstatement of the concept of a "nation state." This makes and will continue to make it more difficult to settle and resolve the conflict, and ensures that it will be even more protracted and intractable. An Asymmetrical Conflict, usually occurring between state entities and organized armies on the one side, and on the other non-state actors, in the guise of terror and guerilla organizations (Michael, 2009), falls by definition into the category of such protracted conflicts and is their ultimate manifestation.

Today more and more conflicts erupt between minority groups and hegemonies, between states and quasi-state entities or between states and terror organizations (various kinds of protracted wars) (Shai, 2006), with asymmetry as a prominent feature. For the most part it is the "weak" party which initiates the conflict, and in some cases employs a strategy of attrition, (Note 8) via terrorist and guerilla means, aimed at reaching a conscious resolution for the "strong" (state) party, with the understanding that a physical resolution is 
unattainable (Shay, 2006). These organizations rely on the population for support and legitimization, as well as cover.

"Low intensity conflict" is a military phenomenon referring to hostilities between a state entity and non-state. It is typified by "erosion" (Note 9) and a lack of resolution, and because it continues over the long term it wears the parties down socially and economically. Another term used in military jargon to describe "low intensity conflict" is "limited conflict." (Note 10)

The primary characteristics of low intensity conflict are: zero-sum game; typically asymmetrical; protracted, long-term conflict with no chance of decisive military resolution; collective punishment by the state entity; blurring the distinction between the military front and the home front; cynical use by the weaker party of psychological warfare and the media; and the absence of a clear time for the conclusion and resolution of the conflict. (Note 11)

\section{The Conflict between Israel and Hamas in Gaza}

Hamas (an acronym for Harakat al-Muqāwamah al-'Islāmiyyah or Islamic Resistance Movement) was founded in 1987 as a socio-religious-political and military movement of fundamentalist Sunni Palestinians. Its activities are almost entirely concentrated in the Gaza Strip (Schiff and Yaari, 1990). The movement's members oppose the existence of the State of Israel, believe that all territory under Israeli sovereignty belongs to the Muslim Waqf, and believe it is the duty of every Muslim to restore it to the Palestinians. The movement's objective is the establishment of a formal Palestinian state where the State of Israel currently stands.

The relationship between Israel and Hamas has been through many crises. (Note 12) Their relationship corresponds to the characteristics of conflicts described above: it is protracted and intractable; it overlaps and interlocks with other conflicts; and it exists simultaneously on a number of levels. Furthermore, the conflict between the two parties exists within the Normal Relations Range (NRR) coined by Edward Azar; Any deviation towards escalation - in our case, a declaration of war - could result in region-wide danger, affect the interests of actors in the international arena (Egypt and Turkey directly, Iran indirectly), and hence give rise to international intervention in such a way as to suppress or reduce the level of violence and cause it to return to the "normal" range. At the same time, a trend towards increasing appeasement, extending beyond the lower threshold of the NRR towards cooperation, would create domestic pressure to renew and escalate violence and revert to the "normal" relations range.

Over time there has been a sharp rise in the level and extent of violence in the conflict, which reinforces the military standing of Hamas but brings the conflict no closer to resolution. We believe that transforming the conflict by means of the ceremony of a declaration of war, has the power to change the existing structure of power thereby creating the necessary conditions for resolving the conflict.

\section{Discussion: The Contribution of a Declaration of War to the Transformation of the Conflict}

This section examines the effect of a declaration of war on the conflict between Israel and Hamas in Gaza. The first part discusses the advantages and disadvantages of a declaration of war (7.1 and 7.2); the second describes the types of transformation to which a declaration of war can cause (8); the third presents fomenters and mollifiers of a declaration of war (9). This will allow for a more balanced examination of the strategic considerations facing Israel in the difficult political and strategic decision-making process vis-à-vis the conflict with Hamas.

\subsection{The Advantages of a Declaration of War}

A formal declaration of war unambiguously assigns responsibility to the authorities concerned. It also serves to inform the entire nation that civilian life is about to change and that the population will have to make many sacrifices. Another important advantage is that such declaration grants the authorities political and moral legitimization to initiate a war on behalf of the nation and to direct military forces as it deems fit. Finally, the declaration through a public binding legal procedure might even prevent the advent of other unnecessary wars (Sidak, 1991), as was hoped by the creators of the declaration of war in the last century.

Furthermore, the declaration of war communicates a very real threat, both for the opposing party and for the declaring nation itself, that the nation is ready and willing to use all its power, allocate all necessary resources to the war effort, and adjust its priorities accordingly (Sidak, 1191: 41). Thus, it represents a shift in position and beliefs and is the direct result of a learning process (LeVine) as well as an expression of the "ripeness" (Zartman, 1985) of the leadership. One example is President Bush's declaration of war on terror in 2001, which delineated the interests of the United States and specified the measures that would be undertaken to defend them. Beyond authenticity, a declaration of war announces that this is not the private action of any single individual or marginal 
group, but one backed by the entire nation, united in its support and authorizing its representatives to declare war. Hence a declaration of war is a "collective act", a fact conveying power and advantage.

A declaration of war can, of course, result in actual warfare. Among the advantages of this possibility are:

\subsubsection{The Arena Is Moved From the Heart of the Population to a Defined Front}

Currently the greatest challenge facing the IDF, different from other Western armies, is that the war is conducted against an enemy that deliberately sacrifices its own people and tries to lure Israel into killing innocent civilians (Kemp, 2009). By its very definition, a declaration of war can help transfer that arena to its natural location, viz. the battlefield, or can create such an arena.

\subsubsection{Cessation of the Conflict's Protracted Nature and Erosion}

Endless conflict and long-term exhaustion exposes Israel's relative disadvantage vis-à-vis the enemy, which is a terror organization. In order for Israel to maximize its advantages, it must create a situation where warfare is concentrated on a single defined front, achieve decisive and conclusive military resolution on that front, and only then move on to the next one. Any other situation will dilute Israel's forces and result in civilian and political erosion and eventually failure.

Moreover, Israel is unable to withstand a war of attrition precisely because it is a democracy. The population's trust in the State to provide all its needs in terms of resources and welfare ("trust and coherency in the government-army-civilian triangle" (Tira, 2008: 68)), will be to its detriment in the event that the low intensity conflict lasts long enough to damage the Israeli economy and civilian morale.

A declaration of war will help break the paradox of asymmetry to Israel's benefit. It is well known that most IDF units were designed for high intensity warfare and trained accordingly even though since 1982 they have actually been more engaged in a war on terror and guerilla warfare (Zalmanovitch, 2006). Therefore, paradoxically, a switch to high intensity warfare following a declaration of war would transform the asymmetry in Israel's favor (Weiner, 2006).

\subsubsection{Legitimization for a War on Terror, and in Particular the Use of Military Force}

The prohibitions on the use of force or limitations on proportionality laid down in international law apply for the most part to situations that are defined as conflicts, rather than to war. Subject to such limitations, a nation that finds itself at war may do anything in its power to defend itself. The realm for military action and possibilities for maneuvers increase, since Israel would be in a situation where the use of force is expected, permitted, and necessary. If the enemy is unable to win a war, but for many years has engaged in a low intensity conflict, a declaration of war will transform disadvantage to advantage:

Armed opposition groups are not able to win a direct confrontation with regular armed forces because they lack firepower, but they can win small local engagements, keep large numbers of regular forces tied up and, perhaps, prevent control by the armed forces of the whole territory (Rogers, 2004).

7.1.4 A Superior Collaboration between the Political and Military Echelons and Creation of a Dialogue between the Two

A declaration of war will force the political echelon to clarify its political directive and encourage dialogue regarding the nature of the war to be conducted, the type of resolution desired, the political objective from which the military operation is derived, and ways to achieve that objective, i.e. "the relationship between Ends and Means" (JOE, 2010). A declaration of war forces dialogue and coordination (by virtue of the law), not required in a targeted response or sporadic operations.

\subsubsection{Determining the Rules of the Game}

War, by nature, is a scenario in which each party defines its objectives differently and views the ultimate outcome differently. If Hamas has thus far laid down the rules, a declaration of war would enable Israel to regain control and have the upper hand by means of advantageous characteristics (superior military capability). "A party that enforces the nature of the war it is suited for, can act effectively to implement its goals, whereas the other party will be less relevant from the outset" (Tira, 2008: 68).

\subsubsection{Subordinating the Struggle between the Parties to War Laws}

Hamas is aware that Israel and other Western armies operate according to international law. Accordingly, Hamas, which does not adhere to the international rules of war, does everything it can to exploit the limitations which its enemy imposes on itself. It works on the basic assumption that Western armies will act largely according to the laws of war and for this reason adopts an intentional policy of acting outside of those laws. In fact this forms the 
basis of its operational doctrine (Kemp, 2009).

\subsection{The Disadvantages of a Declaration of War}

(1) Apart from the irrelevance of a declaration of war in the present era, there is no overall agreement about the desirability of using it today or at all. Moreover, a declaration of war could lead to an internal rift or to widespread panic, and not necessarily to a closing of ranks or an outburst of patriotism among the Israeli public.

(2) A declaration of war could be construed as tantamount to granting legitimization to a movement which is defined and known as a terror organization.

(3) It can even be argued that an act which is not used, and was abandoned during the century in which it was created and legislated, becomes as irrelevant on the political front as on the legal front. Furthermore, at least for the global community, a major disadvantage of a declaration of war is that it opens up a front that could lead to Israel's de-legitimization and hurt the country's interests with Egypt, Iran and the USA.

(4) Since war is designed to serve policy and complement diplomacy, there should first be an examination of whether any coherent policy is in place regarding the Gaza Strip. Such an examination shows that Israel has not yet resolved its basic dilemma about Gaza. On the one hand Israel needs to assure military control in the territories bordering Israel to prevent high-trajectory missiles from being fired into Israel. On the other hand continued control perpetuates accusations from the opposing side, including Hamas, that Israel is an occupying and oppressive power. In that case, occupation of the territories where the firing originates could play into the hands of the enemy (Shay, 2010). Under the circumstances it is in Israel's interest to have a Hamas government which is effective and responsible towards the Palestinian population in Gaza, but militarily weakened and deterred with regard to Israel.

(5) Although one of the main contributions of a declaration of war is to express the determination and decisiveness of the political ranks, in a place with no history of declarations of war, determination or persistence, or coherent policy on the part of political ranks, a declaration of war could actually deliver a message of lack of reliability, and be more damaging than beneficial to Israel.

\section{The Transformations Created by a Ceremony of Declaration of War in the Conflict between Israel and Hamas in Gaza}

Declaration of war as we propose to understand it in this article is used for neutralizing the violent dimension of the conflict which via its constant and persistent presence overshadows the ability to cope with all other aspects of the conflict, therefore leaving no room for using the diplomatic channels for settling the conflict. As described above, declaration of war is a speech act and therefore has a transformative potential to generate a new status between the parties. Hence, our primary claim in this article is that declaration of war has the power to create a substantial transformation in the conflict between Israel and Hamas (Botes, 2003; Kriesberg, 2008) so long as it is reconstructed in its new anthropological meaning.

As mentioned above, Väyrynen (Väyrynen, in: Botes, 2003; Väyrynen, in: Romsbotham, Woodhouse \& Miall, 2005(3), 205) denoted several types of possible transformations. We propose to examine them in the context of the conflict with Hamas as follows:

\subsection{Structural Transformation}

The transformation accurse in the relationships between the parties. The conflict between Israel and Hamas cam demonstrate three ways of such transformation:

\subsubsection{Declaration of War as Recognition of Hamas as a State}

In this case, when Israel performs a declaration of war, it transforms the relations between the parties from state/non-state relations to state/state relations. As a result, Hamas may have to submit to war laws or other international norms. Although it may seem contradictory to one's initial intuition, we maintain that "upgrading" the enemy's status, will break the asymmetrical dimension of the conflict while paradoxically allowing Israel to express its military advantage to resolve the conflict. Although it is unclear whether it can be done legally, at least in the perceptional sense, it is possible to "declare" Hamas as a state through declaration of war. In other words, a pro-active strategy (declaration of war) will create a change within Hamas, forcing change in the attitude and behavior of Hamas and allowing for management of the conflict. This way, declaration of war is a "generator" for learning processes and ripeness (Zartman, 1985) of the leadership of Hamas and an important part on the lead towards resolution. 


\subsubsection{Declaration of War as Recognition of Hamas as a Belligerent}

Declaration of war serves here as recognition of the legitimacy of Hamas by marking them as equal belligerent in this conflict, since one declares war on an entity that is equal to it.

Being that declaration of war is a complex phenomena, such transformation can be viewed as both an advantage and disadvantage for Israel's strategic interests: alongside the advantage of breaking the asymmetry, it also gives legitimacy to the other party by labeling its military arm as a proper state army in a conflictual situation. This demonstrates the dialectical aspect of declaration of war.

\subsubsection{Structural Transformation through a Change in Israel's Policy towards Hamas}

Through complex learning (Levy, 1994) the leadership will change its foreign policy. A declaration of war will clarify how the leadership sees the conflict - are they fighting criminals or soldiers? Declaration of war will label the conflict as "military" with no room for ambiguity.

\subsection{Actor Transformation}

The Israeli leadership adopts new goals and objectives since a declaration of war forces them to define clear and decisive policy to support the need for warfare. Although a declaration of war was neglected as a formal step prior to opening hostilities, the need to define clear objectives still exists. In this sense, it is not the declaration itself that transforms the conflict towards resolution, but the fact that the political echelon is forced to define objectives for policy making as well as for military action.

We maintain that this transformation will also shift the conflict from low intensity to high intensity - war. The need for Israeli leadership to develop objectives may help creating a strategy towards defeating Hamas.

\subsection{Declaration of War Serves as a Message of Credibility and Decisiveness}

In other words, a declaration of war is a clear declaration of intentions. Since we view a declaration as a ceremony, it accompanies a collective undergoing a major change (Terner, 2004). This aspect is not drawn directly from the Conflict Transformation approach but in our view is defined as crucial for creating a combination between a cognitive process (learning) and a behavioral one (ripeness) when the Israeli leadership undergoes a learning process that leads to a change in its attitude, policy and strategy. Harkabi suggests that "the shift towards war is an event, an actual action and not only a behavior, and such action depends on one decisive decision" (Harkabi, 1990, 318). Such an "event" is the ceremony of declaration of war which leads to a Structural Transformation (Väyrynen, in: Botes, 2003; Väyrynen, in: Romsbotham, Woodhouse \& Miall, 2005(3), 205).

Analysis of those types of transformations challenges the traditional conception of a dichotomy between diplomacy and war, where declaration of war was firmly a strategic move and not a diplomatic one. Through our new conceptualization, we place a declaration of war as a tool for policy, which marks declaration of war as diplomatic in nature having the potential to contribute greatly to the settlement of the conflict with Hamas with no actual warfare included. This approach is exemplified in the transformation of the conflict from state/non-state to state/state relations, and in the transformation of Hamas to an equal belligerent. In this sense, a declaration of war can be viewed as an extension of the diplomacy, with "strategy" only beginning when (and if) warfare commences. Placing a declaration of war in this new framework - policy making - gives it a new interpretation and allows for understanding its proper contribution to conflict resolution.

\section{Fomenters and Mollifiers of a Declaration of War}

While a declaration of war could bring about a transformation that might contribute to the chances of a resolution; the same transformation could also work against Israel's strategic interests. Therefore it is important to conceptualize the factors having the power to foment and to mollify a declaration of war. It should be noted that the same factor might appear to simultaneously foment and mollify, as might be expected of something as complex and dichotomous as a declaration of war.

\subsection{Mollifiers}

Acclimatization of the Israeli public. Alongside a sharp increase in the level and extent of violence, the Israeli public becomes accustomed to a constant state of emergency, anxiety and threat. As the intensity of the conflict rises on the NRR axis, adjustment to it reaches proportionately new and surprising levels. Throughout the peaks we observe the population's resilience as it adapts to this changing and escalating reality. Therefore we view such acclimatization as a mollifier to declaring war.

National resilience. National resilience is defined as the level of preparedness of a nation's home front to cope 
with crises, in relation to various threatening scenarios, with the involvement of all bodies comprising emergency deployment, such as health and education systems, home front security, including defense measures, and more (Elran, 2010). Most prominent of them all is "social resilience," which translates into civilian readiness to cope with the harsh consequences of a military conflict, and a subsequent rapid recovery and return to routine functioning in an effort to avoid the public becoming overwhelmed and fragmented. Quick acclimatization of the nation gives rise to the emergence of national resilience, which mollifies the motivation of political echelons to declare war.

Time and international legitimization. Time works against Israel. The longer the duration of bouts of violence, the greater the international pressure and the more the country's resources dwindle. The act of declaring war turns the dialogue on human rights into a strategic and political one, with the result that Israel is ultimately unable to convert its clear military advantage into a decisive resolution. This is what happened, for instance, in the last operation (Pillar of Defense) that Israel conducted in Gaza in November 2012, which was seen by many as a "rerun" of Operation Cast Lead, with no resolution forced on Hamas. Hence, the longer the conflict continues, the less likely a declaration of war will be issued.

\subsection{Fomenters}

Level and extent of violence. Over the many years of the present conflict Hamas has markedly escalated and increased the militancy of its measures against Israel and its civilian population. While building up its military and technological capability, Hamas does not consider itself subject to the laws of war. As a result, the organization increases the impact of its success by committing terror attacks ever closer to the center of Israel. Operation Pillar of Defense in November 2012 provides a clear example.

Overall, since Hamas took power, the number of terror attacks originating from Gaza has grown: from 2,137 in the year when Hamas came to power (as compared to 1,831 during the previous year) to 3,023 in 2008, prior to the start of Operation Cast Lead (www.shabak.gov.il). Such a sharp increase indicates an ongoing rise in the intensity of the conflict; hence the pressing need to bring it to an end. The rising level of violence then can be viewed as a fomenter to declaring war.

Establishment of a state governed by Hamas. As Hamas progresses further towards establishing itself as a state, it becomes more vulnerable to threats by Israel. Cost-benefit considerations change as responsibility to its civilian population increases and Israel's superior military capability has a greater influence in those calculations. (Note 13) Hence, the more established Hamas becomes, the easier it will be for Israel to threaten it by declaring war.

\subsection{Factors that Foment and Mollify Simultaneously}

International legitimization of the use of force. Israel suffers from a fundamental international de-legitimization of its actions, especially in relation to the use of force against a civilian population. Following Operation Cast Lead (2008-2009), and notwithstanding IDF's efforts to avoid collateral injury to civilians, the Goldstone Report was severely critical of Israel's use of force in the Gaza Strip. (Note 14) In May 2010, a Turkish flotilla (the MV Mavi Marmara) arrived off Gaza, further undermining Israel and its legitimization. Israel's inherent need to legitimize its actions in the broader international community could be construed as both a mollifier and a fomenter. On the one hand the country's need for legitimization could lead to a declaration of war under international law. On the other hand, Israel's fear of being perceived as hostile by the world in general and its need for external legitimization act as mollifiers.

Internal legitimization of the use of force. The democratic system dictates the need to obtain domestic legitimization for the political regime, but "the complexity of strategic thought and the paradoxical principles on which it is based make it a difficult matter to market and explain [...] to the Israeli public [...]. Such paradoxical inconsistencies, the synergies of opposites and contradictions, are almost impossible for the general public to grasp" (Michael, 2009). Therefore, the need for legitimization from the Israeli public if seen as a unifying act promising a widespread shift in consciousness could prove a fomenter. On the other hand, it could turn out to be a mollifier in a situation where society is divided, or if the political echelons anticipate that the public will not support a declaration of war and will be unwilling to join the ranks of the struggle.

"Legalization" in political and military echelons: There is a significant difference between the way the ceremony of declaration of war is perceived in the eyes of the law and the way it is viewed from a strategic and anthropological point of view. The more the dialogue veers towards the legal, the more will it mollify a possibility to declare war. The more strategic and anthropological the focus of the dialogue, the more it is based on a broad interdisciplinary view, the more likely it is to foment the issuance of declaration of war. 


\section{Summary}

This article presents a variety of paradigms to examine and take a fresh look at the phenomenon of a declaration of war on the assumption that a declaration can make a significant contribution to settling protracted conflicts characterized by extreme violence. Instead of looking at a declaration of war from a one-dimensional, strictly legal angle, it can instead be seen as a ceremony and a means for transformation. The connection and overlap between various contrasting disciplines is actually helpful in redefining the phenomenon and highlighting the contribution it can make, a contribution which for many decades was ignored and overlooked by decision makers.

Despite the clear disadvantages of declaring war, a declaration has the ability to alter the asymmetrical dimension of the conflict and promote more balanced relations between enemies. Among other things, this means legitimizing the struggle of the other party, i.e. Hamas, to the conflict. Although that statement might sound contradictory to the political rationale that has hitherto shaped political activity and policy towards Hamas, it may be in line with another kind of strategic rationale, whereby a transformation in the very structure of the conflict, affected by altering the balance of power and asymmetry between the parties, can result in resolution of the conflict.

In light of the fomenters and mollifiers in the latter section of this article, there needs to be a broader examination of the impact a declaration of war can have and the ways in which it can contribute to the transformation of protracted conflicts, including those that are characterized predominantly by violence, in other parts of the world. This will lead to a better understanding of the phenomenon of a declaration of war and suggest a meaning and interpretation that may have value beyond the conflict between Israel and Hamas. Thus we will be able to define a conceptual framework that will help explain the phenomenon, further discussion, and encourage a dialogue that will also spill over into other related matters.

\section{Notes}

Note 1. For further detail, see:

- Edward E. Azar, Jureidini \& McLaurin, "Protracted Social Conflict: Theory and Practice in the Middle East”, Journal of Palestine Studies, 8(1) (1978): 41-60.

- Louis Kriesberg, "Interlocking Conflicts in the Middle East", Research in Social Movements, Conflicts and Change 3 (1980): 99-119.

- Rouhana \& Daniel Bar-Tal: "Psychological Dynamics of Intractable Ethno-national Conflicts: The Israeli-Palestinian Case", American Psychologist 53 (1998): 761-770.

Note 2. For further detail on the characteristics of limited conflict, see: Kobi Michael, "Limitations of Strategic Maneuver: The Israeli Case", Infinity Journal 1(4) (2011): 12-16.

Note 3. Kellogg-Briand Peace Pact (Treaty Providing for the Renunciation of War as an Instrument of National Policy, 46 Stat. 2343 (1929); TS 796; 2 Bevans 732) and the Charter of the United Nations: The treaties determine a ban on the use of war as part of national policy. The states which are parties to the treaties undertake to resolve disputes only by peaceful means. Such treaties are the first step towards invalidating legitimization of the use of force. Col. (Res.) Daniel Reisner, Adv., goes even further in stating that declarations of war are no longer legal by virtue of such treaties (in an interview between the writer and Col. Reisner, Adv. on December 11, 2011).

Note 4. For more detail on International Law, see:

- David P. Cavaleri, The Law of War: Can $20^{\text {th }}$ Century Standards Apply to the Global War on Terrorism?, Kansas: Combat Studies Institute Press (2005).

- Ruby Seibel, "International Law in the Test of the Gaza Operation", Strategic Update 11(4) (2009): 22-25.

- Yehoshefat Harkabi, War and Strategy (4 ${ }^{\text {th }}$ Printing), (Tel Aviv: Ma'arachot, 1990).

- Raphael Bitton, "War Laws as a Comprehensive Framework for the Arrangement of Institutional Killing", Law and Army 19 (2007): 245-323.

Note 5. For more detail on existing approaches in conflict management and resolution, see: Robert A. LeVine \& Donald T. Campbell, Ethnocentrism: Theories of Conflict, Ethnic Attitudes and Group Behavior (Wiley: New York, 1972). 
Note 6. "The old paradigm of conflict resolution is clearly being revised, if not in the process of being replaced" (Botes, 2003).

Note 7. For further detail, see: Rouhana \& Bar-Tal (1998).

Note 8. "Strategy of Attrition" is defined as a military modus operandi with political objectives, whose function is the gradual erosion of military power. The aim is to prevent the enemy from achieving military victory. The weaker side will make every effort to drag the conflict out long term in the hope of inflicting severe damage and delegitimizing the stronger side, as well as making heavy use of psychological warfare through the media aimed at cumulative erosion and exhaustion ("Between Resolution and Victory", in Iyunim B'bitachon Leumi, Edition 2, July 2001).

Note 9. Erosion is a strategy on the part of the weaker side to the conflict, which employs it in an effort to prevail over the enemy. In effect it means long-term, systematic attrition in the form of cumulative physical, financial and emotional damage which gradually erodes the determination of society (Nir Shmuel, "The Nature of Limited Conflict", in The Limited Conflict, eds. Hanni Golan and Shaul Shay, 19-45).

Note 10. H .Golan, S. Shay (2004), "The Limited Conflict”. Tel Aviv: Ma'arachot.

Note 11. For more detail, see: Yaacov Bar-Siman-Tov, "Reciprocal Relations between Conflict Management and Conflict Resolution", in: The Israeli-Palestinian Conflict: from Peace Process to Violent Confrontation, 2000-2005, Yaacov Bar-Siman-Tov (Ed.) (Jerusalem: Jerusalem Institute for Israel Studies, 2005), 16-52.

Note 12. From the movement's election victory (2006), through Operation Cast Lead (2008-2009) and Operation Pillar of Defense (November 2012).

Note 13. This clear view is found in Azar Gat. Is war declining - and why? Journal of Peace Research, 50(2), (2012): 149-157.

Note 14. Goldstone Report: http://image.guardian.co.uk/sys-files/Guardian/documents/2009/09/15/UNFFMGCR eport.pdf

\section{Copyrights}

Copyright for this article is retained by the author(s), with first publication rights granted to the journal.

This is an open-access article distributed under the terms and conditions of the Creative Commons Attribution license (http://creativecommons.org/licenses/by/3.0/). 